\title{
Study of lead and nickel resistance mechanism in Enterobacter species
}

\author{
Nirbhavane $\mathbf{H ~ M}^{1}$, Bagde $\mathrm{U}^{2}$,** $^{*}$ \\ ${ }^{1} \mathrm{Ph}$. D Scholar, ${ }^{2}$ Ex Professor \& HOD, Microbiology Laboratory, Department of Life Sciences, University of Mumbai, \\ Vidyanagari, Mumbai, Maharashtra, India
}

*Corresponding Author:

Email: bagdeu@yahoo.com

\begin{abstract}
The aim of this study was to understand the mechanism of resistance towards the heavy metal Lead and Nickel using resistant and sensitive Enterobacter spp. The cellular biochemistry of this microorganism was checked with the help of estimations of dehydrogenases activity, and at the molecular biology level determination of Lead and Nickel resistant plasmid through Agarose gel Electrophoresis. The Minimum inhibitory concentration (MIC) determined was $100 \mathrm{ppm}$ (Lead) and $50 \mathrm{ppm}$ (Nickel) in sensitive Enterobacter spp. that completely inhibited the growth, and activity of dehydrogenases of the TCA (Tricarboxylic Acid) cycle. The tolerance level of Lead and Nickel in the resistant Enterobacter spp., were found to be $300 \mathrm{ppm}$ and $200 \mathrm{ppm}$ respectively. Mechanism of resistance was found to be the presence of the resistance plasmid.
\end{abstract}

Keywords: Lead, Nickel, Resistant, Sensitive, Enterobacter, Mechanism.

\section{Introduction}

Microorganisms have acquired a variety of mechanisms for adaptation to the presence of toxic heavy metals. Among the various adaptation mechanisms, metal sorption, mineralization, uptake and accumulation, extracellular precipitation and enzymatic oxidation or reduction to a less toxic form, and efflux of heavy metals from the cell has been reported. ${ }^{1-4}$ The mechanism of resistance towards the heavy metals by the microbial cells has been studied throughout the world in regards with their mode of action. In various pathogens the phenomenon of resistance has been found to be related with some essential activities of cell metabolism, such as Permeability of the cell membrane, the synthesis of macromolecules like protein, Deoxyribonucleic acid, Ribonucleic acid, the electron transport and enzyme activity, genetic alterations and the whole cell growth task. ${ }^{5-8}$

Overall, the structural and functional characteristics of antibiotic resistance share common themes with those of metal resistance. ${ }^{9-10}$

In this study we have tried to ostensibly appraise the mechanism of resistance of heavy metals Nickel and Lead with the sensitive and resistant Enterobacter species, which is previously tested with the antimicrobials Ceftazidime, Moxifloxacin and Nalidixic acid. $^{11}$

\section{Materials and Methods \\ Bacterial species and its cultivation}

The strains of resistant and sensitive Enterobacter spp. were obtained from BAC TEST Laboratory Nashik, Maharashtra and stocked in this laboratory. This particular pathogenic microorganism was selected for the study after testing various pathogens for their susceptibility previously with the antimicrobials and then used towards the heavy metals Lead and Nickel. ${ }^{11}$ These organisms were grown on a nutrient agar at $37^{\circ} \mathrm{C}$ and maintained at $5^{\circ} \mathrm{C}$. The inoculum was prepared in nutrient broth after subculture and 48 hours incubation. The cells of Resistant and sensitive species of Enterobacter were cultured on nutrient agar (NA) (HiMedia India) slants containing Beef extract 0.5g; Peptone 2.5g; Sodium chloride 2.5; Agar 15 in a liter of distilled water. $\mathrm{pH}$ was maintained at 7.4 , slants were incubated at $37^{\circ} \mathrm{C}$ for $24 \mathrm{hrs}$.

\section{Detection of antimicrobial resistance and sensitivity in Bacteria}

Broth dilution Method: The broth dilution method was used to determine the minimum Inhibitory Concentrations (MICs) of antibacterial agents according to the guidelines given by CLSI protocol. ${ }^{12}$ The MH broth and the Heavy metals were purchased from HiMedia India.

Disc diffusion method: Antimicrobial susceptibility of resistant and sensitive Enterobacter Species was determined with the help of disc diffusion method of Kirby et al. ${ }^{13}$ with modification by the CLSI. ${ }^{14,12}$ The sterile discs impregnated in to the solution of heavy metals were used according to its MIC value. The Muller Hinton (MH) Agar was procured from HiMedia India.

Detection of $\boldsymbol{\beta}$ lactamase activity: Detection of $\beta$ lactamase was carried out by Tube method and paper strip method of Idometric Test and Acidometric Test. ${ }^{15}$ and $\beta$ lactamase activity testing was done by Qualitative plate test. ${ }^{16}$ Nitrocefin test was not done due to unavailability of nitrocefin.

Plasmid Isolation: Plasmid Isolation was conducted for separation and analysis of nucleic acid by alkaline lysis method. ${ }^{17}$

Spectrophotometric method: Qualitative determination of DNA was carried out with help of the spectrophotometric method given by Maniatis. ${ }^{18}$ 
Agarose gel Electrophoresis: Agarose gel Electrophoresis of plasmid DNA was done according to the method of Sambrook et al. ${ }^{17}$ Plasmid DNA from Enterobacter resistant species was electrophoresed with DNA ladder in $1.0 \%$ agarose gel slab at $50 \mathrm{~V}$ in Tris Acetate buffer (TAE) running buffer $(0.5 \mathrm{M}$ Tris base, 0.5M EDTA, $1 \mathrm{M}$ Glacial acetic acid). Stained with Ethidium bromide and photographed under UV illumination. The plasmid was estimated by comparing with standard Supermix DNA ladder obtained from Bangalore Genei, (Bangalore, India). It consist of DNA fragments ranges from 500 to $33500-24500 \mathrm{bp}$ generated from number of propriotory plasmids and lambda DNA.

Elimination of resistance due to plasmid: Elimination of resistance due to plasmid was carried out by using the sodium dodecyl sulphate (SDS) treatment described by Tomoeda et al. ${ }^{19}$ An overnight culture of resistant (R) cells in Nutrient broth containing various concentrations of Heavy metals (ppm) and sensitive species cells were diluted up to $10^{3}$ cells $/ \mathrm{ml}$ in broth, and added to the tubes containing 10\% (w/v) SDS and shaken at $37^{\circ} \mathrm{C}$. After appropriate dilutions in saline cells were spread on nutrient agar and the sensitivity discs were placed on it.
Growth curve with various concentrations of Heavy metals: The experiments were carried out in $100 \mathrm{ml}$ Ehrlenmeyer flasks with side arm. These flasks were inoculated with $1.0 \mathrm{ml}$ inoculums prepared as above. The final volume in the flask was $50 \mathrm{ml}$. The Extra pure analytical grade heavy metal Lead was used in form of Lead acetate (Qualigenes fine chemical Ltd. India) Nickel was used in form of Nickel chloride in the experiment (Hi media Mumbai). The final concentrations of Nickel taken were 20,30,40,40, and $50 \mathrm{ppm}$ for the Sensitive species and 50, 100, 150, and $200 \mathrm{ppm}$ for the resistant species. The concentrations of Lead taken for resistant species was in the range of 150 , $200,230,250$ and $300 \mathrm{ppm}$ and for the sensitive species the range was 50,70, 90, and $100 \mathrm{ppm}$.

Dehydrogenase assay: The dehydrgenase assay was performed to determine the dehydrogenase activity according to the procedure of Guha and Mookerjee. ${ }^{6}$

\section{Results}

Results of Growth curve study carried out at different concentrations of Nickel and Lead with the appropriate ranges for MIC and tolerance level for sensitive and resistant species of Enterobacter are shown in Fig. 1 to 4.

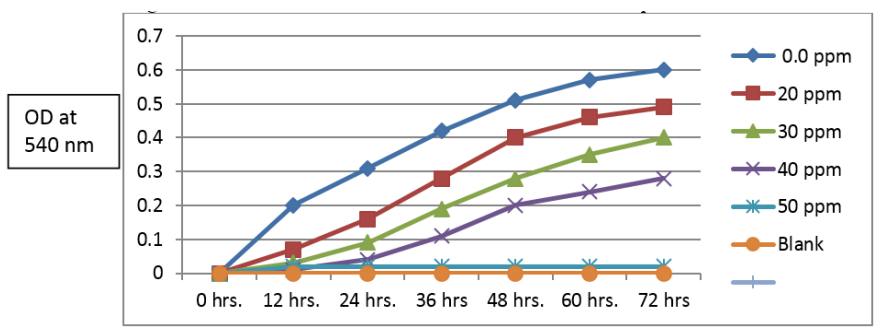

Fig. 1: Growth of Sensitive Enterobacter species up to $50 \mathrm{ppm}$ concentration of Nickel

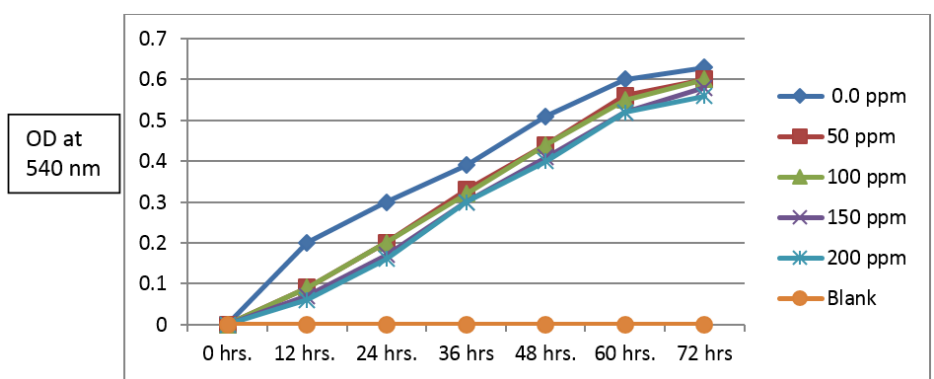

Fig. 2: Growth of Resistant Enterobacter species up to $200 \mathrm{ppm}$ concentration of Nickel

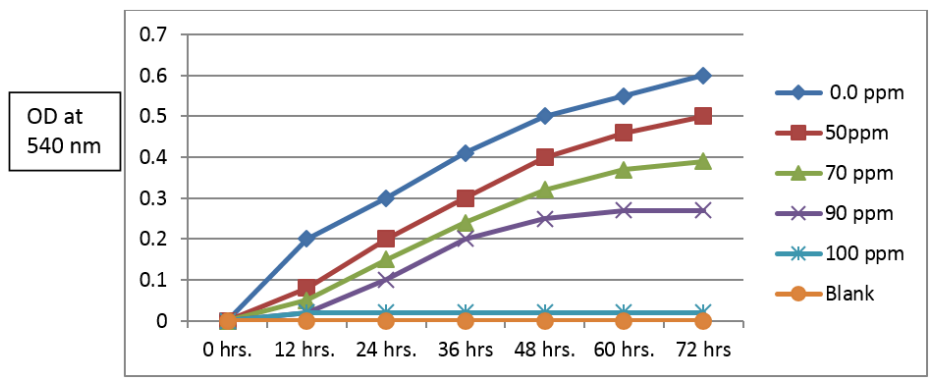

Fig. 3: Growth of Sensitive Enterobacter species upto100 ppm concentration of Lead 


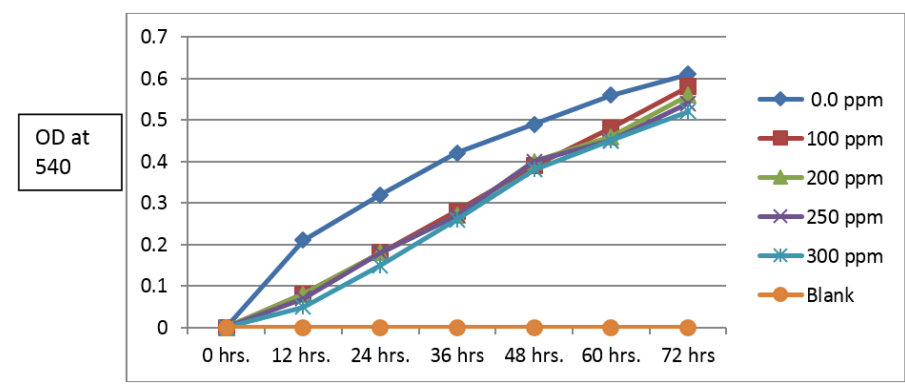

Fig. 4: Growth of Resistant Enterobacter species up to $300 \mathrm{ppm}$ concentration Lead

\section{Growth Inhibition}

Whereas the sensitive strain of Enterobacter was completely inhibited at 50 ppm of Nickel (Fig. 1), resistant strain of Enterobacter tolerated up to $200 \mathrm{ppm}$ concentration of Nickel (Fig. 2). When the sensitive strain of Enterobacter was completely inhibited at $100 \mathrm{ppm}$ of lead (Fig. 3), resistant strain of Enterobacter tolerated up to $300 \mathrm{ppm}$ concentration of lead (Fig. 4).

Table 1: Effect of Heavy metals on sensitive and resistant Enterobacter species

\begin{tabular}{|c|l|c|c|c|}
\hline S. No. & \multicolumn{1}{|c|}{ Pathogen } & $\begin{array}{c}\text { Heavy } \\
\text { Metal }\end{array}$ & $\begin{array}{c}\text { Size of Zone of } \\
\text { Inhibition }\end{array}$ & $\begin{array}{c}\text { MIC value/ } \\
\text { tolerance value }\end{array}$ \\
\hline 1 & Sensitive Enterobacter & Nickel & $25 \mathrm{~mm}$ & $50 \mathrm{ppm}$ \\
\hline 2 & Sensitive Enterobacter & Lead & $20 \mathrm{~mm}$ & $100 \mathrm{ppm}$ \\
\hline 3 & $\begin{array}{l}\text { Resistant Enterobacter } \\
\text { (Before SDS Treatment) }\end{array}$ & Lead & $0 \mathrm{~mm}$ & \multirow{2}{*}{$300 \mathrm{ppm}$} \\
\cline { 1 - 3 } & $\begin{array}{l}\text { Resistant Enterobacter } \\
\text { (After SDS Treatment) }\end{array}$ & Lead & $21 \mathrm{~mm}$ & \multirow{2}{*}{$200 \mathrm{ppm}$} \\
\cline { 1 - 3 } & $\begin{array}{l}\text { Resistant Enterobacter } \\
\text { (Before SDS Treatment) }\end{array}$ & Nickel & $0 \mathrm{~mm}$ & \multirow{2}{*}{$24 \mathrm{~mm}$} \\
\hline 6 & $\begin{array}{l}\text { Resistant Enterobacter } \\
\text { (After SDS Treatment) }\end{array}$ & Nickel & \multicolumn{2}{|c}{} \\
\hline
\end{tabular}

The effect of heavy metals when tested in sensitive and resistant strains in terms of size of zone of inhibition in $\mathrm{mm}$, it was as shown in table 1 . In case of sensitive strain zone of inhibition was $25 \mathrm{~mm}$ for nickel and $20 \mathrm{~mm}$ for lead. In resistant strain zone of inhibition was 0 and $24 \mathrm{~mm}$ for nickel and $0 \mathrm{~mm}$ and $21 \mathrm{~mm}$ for lead before and after SDS treatment respectively.

The growth percentages of sensitive Enterobacter $\left(10^{3} \mathrm{CFU} / \mathrm{ml}\right)$ at $40 \mathrm{ppm}$ and $90 \mathrm{ppm}$ of Nickel and
Lead were found to be $46.66 \%$ and $45 \%$ respectively after 72 hrs. (Table 2). At MIC concentrations of Nickel (50ppm) and Lead (100ppm) there was no growth at all. The growth percentages of resistant Enterobacter at $10^{3}$ $\mathrm{CFU} / \mathrm{ml}$ in $300 \mathrm{ppm}$ and $200 \mathrm{ppm}$ of Nickel and Lead were found to be $88.88 \%$ and $85.24 \%$ respectively after 72 hrs. (Table 3).

Table 2: Growth Percentages of sensitive Enterobacter after 72 hrs at different concentrations of Heavy metals

\begin{tabular}{|l|l|c|c|c|}
\hline Sr. No. & Heavy Metal & Concentration $\mathbf{( p p m )}$ & OD at 540 nm & \% of Growth \\
\hline 1 & Nickel & 0 & 0.6 & 100 \\
\hline 2 & Nickel & 20 & 0.49 & 81.66 \\
\hline 3 & Nickel & 30 & 0.4 & 66.66 \\
\hline 4 & Nickel & 40 & 0.28 & 46.66 \\
\hline 5 & Nickel & 50 & 0.01 & 0 \\
\hline 6 & Lead & 0 & 0.6 & 100 \\
\hline 7 & Lead & 50 & 0.5 & 83.33 \\
\hline 8 & Lead & 70 & 0.39 & 65 \\
\hline 9 & Lead & 90 & 0.27 & 45 \\
\hline 10 & Lead & 100 & 0.02 & 0 \\
\hline
\end{tabular}

Table 3: Growth Percentages of Resistant Enterobacter after $72 \mathrm{hrs}$ at different concentrations of Heavy metals

\begin{tabular}{|c|l|c|c|c|}
\hline Sr. No. & Heavy Metal & Concentration (ppm) & OD at 540 nm & \% of Growth \\
\hline 1 & Nickel & 0 & 0.63 & 100 \\
\hline 2 & Nickel & 50 & 0.6 & 95.23 \\
\hline 3 & Nickel & 100 & 0.6 & 95.23 \\
\hline 4 & Nickel & 150 & 0.58 & 92.06 \\
\hline
\end{tabular}




\begin{tabular}{|c|l|c|c|c|}
\hline 5 & Nickel & 200 & 0.56 & 88.88 \\
\hline 6 & Lead & 0 & 0.61 & 100 \\
\hline 7 & Lead & 100 & 0.58 & 95.08 \\
\hline 8 & Lead & 200 & 0.56 & 91.80 \\
\hline 9 & Lead & 250 & 0.54 & 88.52 \\
\hline 10 & Lead & 300 & 0.52 & 85.24 \\
\hline
\end{tabular}

\section{$\beta$ Lactamase detection}

It was observed that there was no decolorization occurred in 5 minutes in Idometric method within the tube or on the strip. Violet to Yellow color change was not observed within 5 minutes in Acidimetric method. No yellow color was noticed around the colony within 60 minutes in Qualitative plate test .Thus $\beta$ Lactamase was not detected.

\section{Dehydrogenase Assay}

The percentages of activity of various dehydrogenase enzymes found in the resistant Enterobacter were tested in citric acid cycle substrate
Glutamate, Isocitrate, Ketoglutarate and Succinate at MIC concentration of Heavy metal Nickel and Lead at $200 \mathrm{ppm}$ and $300 \mathrm{ppm}$ respectively. The activity of Glutamate dehydrgenase, Isocitrate dehydrogenase, Ketoglutarate dehydrogenase and Succinate dehydrogenase was measured as $68.82 \%, 80.85 \%, 64.0$ $\%$ and $82.35 \%$ respectively in resistant Enterobacter treated with Nickel. (Table 4) The resistant Enterobacter showed the dehydrogenase activity Glutamate dehydrgenase $73.68 \%$, Isocitrate dehydrogenase $83.01 \%$, Ketoglutarate dehydrogenase $68.62, \%$, and Succinate dehydrogenase $81.25 \%$ when treated with Lead(Table 5).

Table 4: Effect of Nickel (200 ppm) on the activity of dehydrogenases enzymes in resistant Enterobacter

\begin{tabular}{|c|l|c|c|c|c|}
\hline S. No. & \multicolumn{1}{|c|}{ Enzymes } & OD of Control & OD of Test & \% of Activity & $\begin{array}{c}\text { \% of } \\
\text { Inhibition }\end{array}$ \\
\hline 1 & Glutamate Dehydrogenase & 0.51 & 0.35 & 68.62 & 31.18 \\
\hline 2 & Iso citrate Dehydrogenase & 0.47 & 0.38 & 80.85 & 19.15 \\
\hline 3 & Ketoglutarate Dehydrogenase & 0.5 & 0.32 & 64 & 36 \\
\hline 4 & Succinate Dehydrogenase & 0.51 & 0.42 & 82.35 & 17.65 \\
\hline
\end{tabular}

Table 5: Effect of Lead (300 ppm) on the activity of dehydrogenases enzymes in resistant Enterobacter

\begin{tabular}{|c|l|c|c|c|c|}
\hline S. No. & \multicolumn{1}{|c|}{ Enzymes } & OD of Control & OD of Test & \% of Activity & \% of Inhibition \\
\hline 1 & Glutamate Dehydrogenase & 0.57 & 0.42 & 73.68 & 26.32 \\
\hline 2 & Iso citrate Dehydrogenase & 0.53 & 0.44 & 83.01 & 16.99 \\
\hline & $\begin{array}{l}\text { Keto glutarate } \\
\text { Dehydrogenase }\end{array}$ & 0.51 & 0.35 & 68.62 & 31.38 \\
\hline 4 & Succinate Dehydrogenase & 0.48 & 0.39 & 81.25 & 18.75 \\
\hline
\end{tabular}

But the activity of all these enzymes in sensitive Enterobacter showed activity such as Glutamate dehydrgenase $25 \%$ and $26.53 \%$, Isocitrate dehydrogenase $31.11 \%$ \& $26.66 \%$, Ketoglutarate dehydrogenase $22 \%$ \& $27.08 \%$, and Succinate dehydrogenase about $27.27 \% \& 28.46 \%$ in Nickel and Lead respectively. (Table 6 and 7 )

Table 6: Effect of Nickel on the activity of dehydrogenases enzymes in sensitive Enterobacter at MIC (50 ppm)

\begin{tabular}{|c|l|c|c|c|c|}
\hline S. No. & \multicolumn{1}{|c|}{ Enzymes } & OD of Control & OD of Test & \% of Activity & \% of Inhibition \\
\hline 1 & Glutamate Dehydrogenase & 0.48 & 0.12 & 25.0 & 75 \\
\hline 2 & Iso citrate Dehydrogenase & 0.45 & 0.14 & 31.11 & 69.81 \\
\hline 3 & Keto glutarate Dehydrogenase & 0.50 & 0.11 & 22 & 78 \\
\hline 4 & Succinate Dehydrogenase & 0.44 & 0.12 & 27.27 & 62.73 \\
\hline
\end{tabular}

Table 7: Effect of Lead on the activity of dehydrogenases enzymes in sensitive Enterobacter strain at MIC(100 ppm)

\begin{tabular}{|c|c|c|c|c|c|}
\hline S. No. & Enzymes & OD of Control & OD of Test & \% of Activity & $\begin{array}{c}\text { \% of } \\
\text { Inhibition }\end{array}$ \\
\hline 1 & Glutamate Dehydrogenase & 0.49 & 0.13 & 26.53 & 73.47 \\
\hline 2 & Iso citrate Dehydrogenase & 0.45 & 0.12 & 26.66 & 73.44 \\
\hline 3 & Keto glutarate Dehydrogenase & 0.48 & 0.13 & 27.08 & 72.92 \\
\hline 4 & Succinate Dehydrogenase & 0.46 & 0.13 & 28.46 & 71.54 \\
\hline
\end{tabular}




\section{Plasmid Isolation and Agarose Gel Electrophoresis}

The purity of isolated plasmid DNA was noted as 1.685 during the qualitative determination after plasmid isolation. Agarose gel Electrophoresis of plasmid DNA isolated from Enterobacter species resistant to Heavy metal Nickel and Lead Showed 3 different bands in lane 7 (Fig. 5) and the Supermix DNA ladder showed bands of different molecular weight in lane 2, while the sensitive species of Enterobacter did not show any band in lane 4. The plasmid DNA has been run along with the DNA ladder for the purpose of conformation only. There are more than 1 plasmid DNA found nearby the bands of ladder having molecular weight of $15000 \mathrm{bp}$ (at lower side), and molecular weight more than $33500 b p$ (both at upper side).

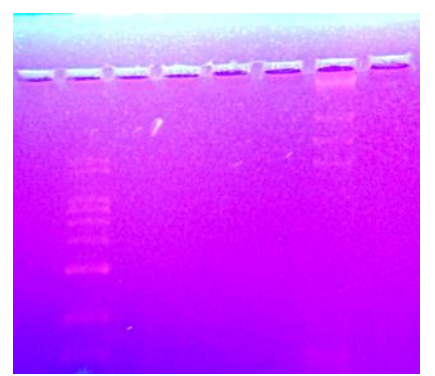

Fig. 5: Agarose gel Electrophoresis of plasmid DNA isolated from Enterobacter species resistant to Nickel and Lead

\section{Plasmid Curing}

Elimination of resistance in resistance was observed in case of resistant Enterobacter spp. after SDS treatment (Fig. 6, and 7). Plasmid was not detected or isolated in sensitive Enterobacter spp (Fig. 8).

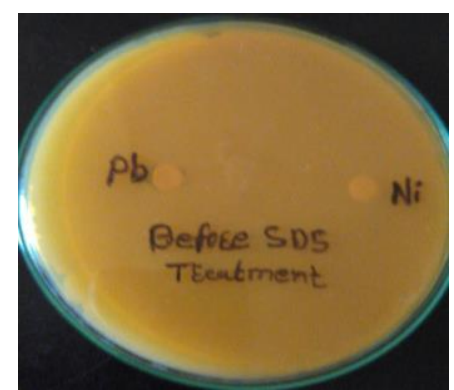

Fig. 6: Resistant Enterobacter with Heavy metal Nickel and Lead before SDS Treatment

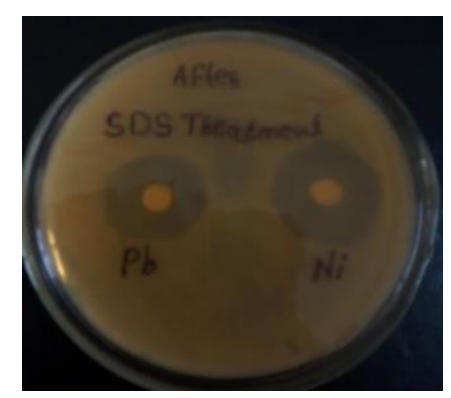

Fig.7: Resistant Enterobacter showing sensitivity towards the Heavy metal Nickel and Lead after SDS Treatment

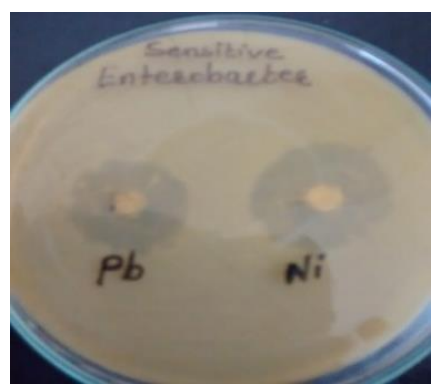

Fig. 8: Sensitive Enterobacter showing sensitivity towards the Heavy metal Nickel and Lead

\section{Discussion}

Many bacterial heavy metal resistances have been studied for many years especially in contaminated regions. Resistance to toxic heavy metals has been found in bacteria from clinical and environmental origins. The genetic determinants of resistance are frequently located on plasmids or transposons..$^{20}$

The objectives of this study were to screen Enterobacter spp. resistance to heavy metals Nickel and Lead, and to determine presence of the plasmid mediated heavy metal resistance.

Enterobacter aerogenes has an ability to completely degrade $0.6 \mathrm{mM}$ Lead concentration in 60 hours while the MIC of Lead for the strain was observed to be 3.6 $\mathrm{mM}$. Also it had an optimum $\mathrm{pH}$ and Temperature of 7.5 and $37^{\circ} \mathrm{C}$, exhibited multiple metal tolerances and showed an improved reduction rate of $\mathrm{Pb}$ in presence of Glucose in the medium. ${ }^{21}$ In the present study the resistance to the heavy metal nickel and lead were found to be $200 \mathrm{ppm}$ and $300 \mathrm{ppm}$ by the resistant Enterobacter. Lee et al. ${ }^{(22)}$ isolated a Nickel-resistant bacterium from soil in order to identify a novel nickel resistance determinant. Using $16 \mathrm{~S}$ rRNA gene sequencing, an isolate was identified as Enterobacter sp. Ni15. This species showed a medium-level (resistant to up to $10 \mathrm{mM}$ ) nickel resistance in nutrientrich media.

The MIC of Lead and Nickel were recorded as 100 $\mathrm{ppm}$ and $50 \mathrm{ppm}$ in this study by the sensitive Enterobacter spp. It is in agreement with the previous studies. The MIC of Pb towards the strains Enterobacter cloacae, Enterobacter ludwigii was noted to be about 4 $\mathrm{mM}$ and other 2 strains of Enterobacter ludwigii showed very high degree of resistance towards $\mathrm{Pb}$. All the different isolates including Enterobacter spp. were tested for the presence of plasmids, showed three distinct bands of open circular, linear and supercoiled plasmid on $1 \%$ agarose gel. ${ }^{23}$ In an investigation reported by Banergee et $\mathrm{al}^{24}$ the isolation and characterization of a potent heavy metal accumulating bacterial strain Enterobacter cloacae B1 from polluted soil at Ghaziabad, India was carried out. The minimum inhibitory concentration of the selected bacterial strain was recorded to be $1100 \mathrm{ppm}$ for lead, $900 \mathrm{ppm}$ for cadmium, and 700 ppm for nickel. 
During the study of growth at various concentrations of Nickel and Lead, sensitive species of Enterobacter showed decreased growth with increasing concentration of these heavy metals due to the increase in toxicity. In a study it is reported that the isolated strain of Enterobacter was found to give low tolerance with $\mathrm{CdCl} 2$ and was found to be highly tolerant to $\mathrm{Pb}(\mathrm{NO} 3) 2$. The MICs of $\mathrm{Cd}^{2+}, \mathrm{Cu}^{2+} \mathrm{Co}^{2+}, \mathrm{Zn}^{2+}$ and $\mathrm{Pb}^{2+}$ were $0.4,1.0,1.0,2.0$ and $3.0 \mathrm{mM} / \mathrm{L}$ respectively. This varying response of tested bacteria might be due to variation in resistance mechanisms. ${ }^{25}$

The result obtained in present study is in accordance with the above statement, as the sensitive Enterobacter showed no growth in $50 \mathrm{ppm}$ of Nickel and 100 ppm of Lead. In 1971 Komura and Lazaki ${ }^{26}$ reported that the MIC of two different metals could be same for any particular microorganism.

It is reported that, the Enterobacter BN4 was able to grow at high concentrations of $\mathrm{Cd} 2+, \mathrm{Zn} 2+$ and $\mathrm{Pb} 2+$ in liquid medium, which might be important for the capacity of this bacterium to survive in different sources of pollution with elevated heavy metal levels. It was found that the toxicity of $\mathrm{Cd} 2+$ was higher than that of $\mathrm{Zn} 2+$ and $\mathrm{Pb} 2+$ that was consistent with the results in solid media in the present study and many other reports. ${ }^{27}$

The growth, and dehydrogenase activity was not inhibited at $300 \mathrm{ppm}$ concentration of Lead and even 200 ppm concentration of Nickel by the resistant species of Enterobacter. The final results of Estimation of Dehydrogenase activity and Growth curve obtained after 72 hours are given in Table $-4,5,6$, and 7 . All these results obtained significantly contributed to the identification of the basic effect and mechanism of resistance. There are remarkable differences seen in the activity of various dehydrogenases between the sensitive and resistant Enterobacter species at various concentrations of heavy metal in the present work. These results are found to be very useful to illustrate one of the well-known mechanisms of resistance that is related to the effect on enzymes in relation with Production of ATP and TCA cycle. There are remarkable differences seen in the activity of various dehydrogenases between the sensitive and resistant Enterobacter species at various concentrations of heavy metal in the present work.

The inhibition of enzyme activity was calculated as $77.08 \%$ and $31.48 \%$ for Glutamate dehydrgenase, $71.11 \%$ and $18.75 \%$ for Isocitrate dehydrogenase, $80.39 \%$ and $38 \%$ for Ketoglutarate dehydrogenase and $72.82 \%$ and $21.56 \%$ for Succinate dehydrogenase in case of resistant and Sensitive Enterobacter respectively. It is in agreement with earlier report ${ }^{28}$ where it is reported that the inhibition of dehydrogenases activity in S. epidermidis as Glutamic 93.4\%, Succinic $84.6 \%, \alpha$-ketoglutaric $85.7 \%$ and Isocitric dehydrogenases $91.7 \%$ and in K. pneumoniae it was $93 \%, 91 \%, 92 \%$ and $89 \%$ respectively. The four dehydrogenases involved in the TCA cycle, glutamic, succinic, $\alpha$ - ketoglutaric and isocitric dehydrogenases were inhibited to a greater extent, when bacterial cells were exposed to arsenic

The activity of all the dehydrogenases was checked after 48 hours of inoculation. As shown in table the activity of enzymes was noted in form of optical density on colorimeter. In case of the resistant Enterobacter the dehydrogenase activity was seen much greater than the dehydrogenase activity found in sensitive Enterobacter. This can surely help to understand the mechanism of resistance of the organism in this study (Table $-4,5,6,7$ ). This is an evidence for the inhibition in generation of ATP molecules. The inhibition of all the four type of dehydrogenases in due course concern with the production of Energy rich compounds and inhibits the growth and multiplication of the cell. It is in agreement with the earlier studies. ${ }^{29,28,8}$

Bacterial plasmids have genes that confer highly specific resistances to $\mathrm{As}, \mathrm{Bi}, \mathrm{Cd}, \mathrm{Cu}, \mathrm{Cr}, \mathrm{Hg}, \mathrm{Zn}$, and other toxic heavy metals. For each toxic cation and anion, generally a different resistance system exists, and these systems may be linked together on multiple resistance plasmids. ${ }^{30}$

Plasmid was isolated and cured successfully which is a big evidence to reveal the resistance mechanism in the present work. In a study ${ }^{(31)}$ the plasmid DNA was isolated from K. pneumonia with approximate size of $4.9 \mathrm{~kb}$. Curing of plasmid was carried out with SDS. Plasmid curing was achieved by growing the strain treatet with SDS. A plasmid isolated from Klebsiella spp. was treated with $10 \%$ SDS that leads to loss of a plasmid. A Strain of Enterobacter (Ent- 5) tolerated high concentrations of copper $(23 \mathrm{mM})$, nickel (16 $\mathrm{mM})$, chromium $(8 \mathrm{mM})$ and cadmium $(14 \mathrm{mM})$. Cured Ent-5 was not able to grow on $\mathrm{Ni}$ and $\mathrm{Cu}$. The sensitivities of the plasmid cured Ent-5 to nickel and copper indicated that copper and nickel resistance is correlated with plasmids. ${ }^{32}$

The absence of B lactamase enzyme in resistant Enterobacter was reported previously. ${ }^{10}$ The availability of reliable data through this type of experiment could be a useful tool in purpose of determination of heavy metal uptake and its metabolism in bacterial cell or antimicrobial drug preparations with the help of heavy metals at the edge of update information. The current status of Nickel and Lead action towards Enterobacter spp., can be understood with help of the obtained results in this study.

\section{Conclusion}

This particular study has highlighted the mechanism of resistance in Enterobacter towards heavy metals Lead and Nickle that was due to presence of resistance plasmid in resistant Enterobacter. Plasmid was not present in Enterobacter sensitive strain. 


\section{References}

1. Mergeay M. Towards an understanding of the genetics of bacterial metal resistance. Trends in Biotechnology. 1991;9:17-24.

2. Hughes MN, Poole RK. Metal speciation and microbial growth, the hard and soft facts. J. of Gen. Micro. 1991;137:725-34.

3. Nies NH. Resistance to cadmium, cobalt, zinc and nickel in microbes. Plasmid, 1992; 27: 17-28.

4. Joshi-Tope G, Francis AJ. Mechanisms of biodegradation of metal-citrate complexes by Pseudomonas fluroescens. Journal of Bacteriology. 1995;177:1889-993.

5. Blundell MR and Wild DG. Inhibition of Bacterial Growth by Metal Salts: The Accumulation of Ribonucleic acid during inhibition of Escherichia Coli by Cobalt Chloride. Biochem. J. 1969;115:213-33.

6. Guha C, Mookerjee C. Effect of cobalt chloride on polypeptide synthesis in Escherichia coli K12. Ind. J.Exptal. Biol. 1978;16:862-4.

7. Bagde US, Varma AK. Effect of magnesium on the toxicity of chromium and lead towards Escherichia coli and A. aerogenes. Curr. Sci. 1982;51(17):830-2.

8. Bagde US, Salvi NC. Mechanism of Nickel toxicity in Salmonella paratyphi-B and Shigella flexneri. Proc. Int.Conf. On Chem. Industry, Bahrain, (Saudi Arabia). 1994;2:1429.

9. Craig BA, Meredith SW, Right RS, McArthur JV. Coselection of antibiotic and metal resistance. Trends in Microbiology. 2006; 14 (4):176-82.

10. Nirbhavane HM, Bagde US. Study of resistance mechanism in Enterobacter spp. with special reference to antimicrobials Ceftazidime, moxifloxacin and Nalidixic acid, African Journal of Microbiology Research, 2015;9(49):2364-73.

11. Ghosh A, Singh A, Ramteke PW, Singh VP. Characterization of large plasmids encoding resistance to toxic heavy metals in Salmonella abortus equi. Biochem. Biophys. Res. Commun. 2000;272:6 -11.

12. National Committee for Clinical Laboratory Standards (NCCLS). Document M 100-S11. Performance standards for antimicrobial susceptibility testing. 9th informational supplement. NCCLS. 2001; Wayen. p. 122.

13. Kirby WM. Extraction of a highly potent penicillin inactivator from penicillin resistant staphylococci. Science. 1994;99:452-5

14. National Committee for Clinical Laboratory Standards (NCCLS).. Document M 100-S22 Performance standards for antimicrobial susceptibility testing. 22nd informational supplement. NCCLS. 1999; Wayen. pp.449.

15. Livermore DM, Brown DFJ. Detection of Beta-lactamase mediated resistance. Journal of Antimicrobial Chemotherapy. 2001;48:59-64.

16. George AM, Levy SB. Amplifiable resistance to TETRACYCLIN, chloromphenicol and other antibiotics in Escherichia coli involvement of non plasmid determined statisc efflux of Tetracyclin. J. Bacteriol. 1983;155(2):534-40.

17. Sambrook J, Fritsch EF, Mantiatis T. Molecular cloning; a laboratory manual. Cold Spring Harbor Laboratory Press, NY, U.S. A. 1989.

18. Maniatis T, Frisch EF, Sambrook J. Large isolation of Plasmid DNA. In Molecular Cloning: A laboratory manual ed. Maniatis T, Frisch EF and Sambrook J. Cold Spring Harbor Laboratory Press N.Y. 0879691360(pbk). 1982;86-96.

19. Tomoeda M, Inuzulka M, Kubo N, Nakamura S. Effective elimination of drug resistance and sex factors in
Escherichia coli by sodium dodecyl sulfate. J. Bacteriol. 1968;95:1078-89.

20. Cervantes C, Chavez K, Vaca S. Mechanisms of bacterial resistance to heavy metals. Rev. Latinoam Microbiol. 1991;33:61-70.

21. Macklin R.L. Isolation and functional characterization of lead-resistant Enterobacter aerogenes (BDUP1) from paint industry effluent contaminated site, FEB. 2013;.22/2:336-42.

22. Lee YK, Chang HH, Lee HJ, Park H, Lee, KH, Joe MH. Isolation of a novel plasmid, pNi15, from Enterobacter sp. Ni15 containing a nickel resistance gene. FEMS Microbiol. Lett. 2006; 257(2):177-81.

23. Gandhi VP, Priya A, Priya, S, Daiya, V, Kesari J , Prakash K, Kumar Jha, A, Kumar K, Kumar N. Isolation and molecular characterization of bacteria to heavy metals isolated from soil samples in Bokaro Coal Mines, India, Pollution, 2005;1(3):287-95.

24. Banerjee GS, Pandey S, Ray AK, Kumar R. Bioremediation of Heavy Metals by a Novel Bacterial Strain Enterobacter cloacae and Its Antioxidant Enzyme Activity, Flocculant Production, and Protein Expression in Presence of Lead, Cadmium, and Nickel. Water Air Soil Pollut. 2015;226:1-9.

25. Abou Zeid AA, Hassanein AW, Hedayat SM, Fahd GAA. Biosorption of Some Heavy Metal Ions Using Bacterial Species Isolated from Agriculture Waste Water Drains in Egypt. J. Appl. Sci. Res., 2009; 5(4):372-383.

26. Komura I, Lazaki K. Mechanism of mercuric chloride resistance in microorganisms. I. Vaporization of a mercury compound from mercuric chloride by multiple drug resistant strains of Escherichia coli. J. Biochem. 1971;70: 885-893.

27. Schulz BJE, Boyle CJC, Siever TN. (Eds.).What are Endophytes? In: Microbial Root Endophytes, SpringerVerlag, Berlin, TN.pp: 1-33. ISBN: 9783540335252.

28. Surve NN, Bagde US. Arsenic Toxicity in Pathogenic Staphylococcus epidermidis and Klebsiella pneumoniae. Int. J. Of Integr. Bio. 2010;2(2):213-21.

29. Surve NN, Bagde US. Silver Toxicity in Pathogenic Staphylococcus epidermidis and Klebsiella pneumoniae. Int. J. Of Integr. Bio. 2009; 7(3):139-43.

30. Silver S, Misra TK, Laddaga RA. DNA Sequence analysis of Bacterial Toxic Heavy Metal Resistances. Biological Trace Element Research, 1989;21:145-63.

31. Akhavan SA, Sharifian S, Zolfaghari MR., Khalily DM, Rashedi H. Study on heavy metal resistant fecal Coliforms isolated from industrial, urban wastewater in Arak, Iran, Int. J. Environ. Res., 9(4):1217-1224, Autumn 2015; ISSN:1735-6865).

32. Unaldi Coral MN, Korkmaz H, Arikan B, Coral G. Plasmid mediated heavy metal resistance in Enterobacter spp. isolated from Sofulo Landfill, in Adana, Turkey. Ann. Microbiol. 2005; 55:175-9. 